\title{
PENERAPAN PSIKOLOGI PADA PERPUSTAKAAN
}

\author{
Nurussakinah Daulay \\ Dosen Fakultas Ilmu Tarbiyah Dan Keguruan \\ Universitas Islam Negeri Sumatera Utara \\ Email: nurussakinah@uinsu.ac.id
}

\begin{abstract}
Abstrak
Tulisan ini berupaya untuk membahas tentang kaitan serta aplikasi dari ilmu psikologi terhadap ilmu perpustakaan. Perpustakaan dianggap sebagai wujud dari inovasi pendidikan. Inovasi pendidikan itu sendiri adalah sebuah inovasi dalam bidang pendidikan atau inovasi untuk memecahkan masalah pendidikan. Fungsi perpustakaan adalah sebagai sumber kegiatan belajar mengajar, membantu peserta didik memperjelas dan memperluas pengetahuan pada bidang studi, mengembangkan minat, bakat dan kebiasaan membaca, membiasakan anak mencari informasi sendiri dan memperluas kesempatan belajar siswa. Dengan kehadiran perpustakaan, merupakan salah satu langkah untuk menangkis tantangan globalisasi dan meningkatkan kualitas sumber daya manusia. Dalam mengembangkan perpustakaan, perlu adanya dukungan dari ilmu-ilmu lainnya, salah satunya adalah ilmu psikologi. Ilmu psikologi adalah ilmu yang membahas tentang perilaku dan kaitannya dengan interaksi terhadap lingkungan. Oleh karena itu keberadaan perpustakaan sebagai unit pengelola informasi sangat penting untuk mendukung terjadinya komunikasi yang efektif di masyarakat.
\end{abstract}

Kata Kunci : Psikologi, Ilmu Perilaku, Ilmu Perpustakaan, Pendidikan.

\begin{abstract}
The aim of this paper is discussing about the relevance and application of psychology to the science library. Library is considered as a form of educational innovation. Educational innovation itself is an innovation in the field of education or innovation to solve educational problems. Library function is as a source of learning and teaching, helping students clarify and expand knowledge in the field of study, develop interests, talents and reading habits, get children to look for information themselves and expand student learning opportunities. With the presence of the library, is one of the steps to fend off the challenge of globalization and improve the quality of human resources. In developing the library, the need for support from other sciences, one of which is the science of psychology. Psychology is the science which deals with the interaction of behavior and its relation to the environment. Therefore, the existence of the library as an information management unit is very important to support the effective communication in society.
\end{abstract}

Key words : Psychology, Science of Behavior, Science of Library, Education. 


\section{PENDAHULUAN}

Pendidikan memiliki nilai yang strategi dan urgen dalam pembentukan suatu bangsa. Pendidikan itu juga berupaya untuk menjamin kelangsungan hidup bangsa tersebut. Sebab melalui pendidikan akan diwariskan nilai-nilai luhur yang dimiliki oleh bangsa tersebut, karena itu pendidikan tidak hanya berfungsi untuk how to know, how to do, dan how to live together, tetapi yang sangat penting adalah how to be, bagaimana agar how to be terwujud maka diperlukan transfer budaya dan kultur.

Pada negara-negara yang sudah berkembang pendidikan menjadi perhatian yang sangat penting bagi masyarakat. Orangorang yang memperdebatkan pendidikan cenderung berpendirian bahwa tujuan pendidikan dasar adalah mempersiapkan generasi muda untuk melanjutkan pendidikan ke jenjang yang lebih tinggi. Menurut Miller [1993] bahwa pendidikan tidak hanya bertujuan mengantarkan peserta didik ke arah kedewasaan, melainkan juga pencapaian perilaku yang lebih luas dan lebih banyak kemungkinan-kemungkinannya.

Standar nasional pendidikan berisi kerangka tentang apa yang harus diketahui, dilakukan, dan dikuasai oleh peserta didik pada setiap tingkatan. Kerangka ini disajikan dalam bentuk pengembangan penguasaan ilmu-ilmu dasar dengan sistematika keilmuan yang dapat dipertanggungjawabkan secara akademik. Standar ini juga disertai dengan standar pembentukan akhlak mulia yang mengutamakan pembentukan sistem nilai untuk mewujudkan manusia Indonesia yang berkepribadian dan beretos kerja.

Salah satu upaya untuk mewujudkan kemampuan dasar adalah perlunya sekolah menjadi suatu lembaga yang dinamis, berorientasi ke masa depan, dan mampu menciptakan lingkungan yang aman. Kehadiran lembaga-lembaga pendidikan formal seperti sekolah dan perguruan tinggi yang berfungsi 
untuk mendidik anak agar menjadi seorang individu yang hebat dan mengembangkan kepribadian anak agar tumbuh dengan kepribadian yang tangguh, kuat dan tahan uji untuk menghadapi kehidupan dan persiangan dalam era globalisasi.

Salah satu fungsi dari lembaga pendidikan formal adalah untuk menghasilkan peserta didik yang cakap dari segi kognitif, maka salah satu cara adalah dengan memfasilitasi sarana dan prasarana guna meningkatkan pemahaman peserta didik, maka kehadiran perpustakaan di tengah-tengah lembaga tersebut adalah merupakan suatu keharusan karena perpustakaan suatu unit kerja tempat menyimpan buku-buku yang terdiri dari berbagai ilmu pengetahuan, dan diatur secara sistematis menurut cara yang sudah ditentukan.

Khususnya perpustakaan di suatu perguruan tinggi sangat membantu mahasiswa di dalam belajarnya. Mahasiswa dapat mempergunakan waktu untuk belajar sendiri dalam menambah ilmu pengetahuan. Dengan membaca koleksi-koleksi buku yang tersedia di perpustakaan sebagai sarana untuk penunjang pelaksanaan program pendidikan diajarkan dan dipelajari serta dikembangkan lebih lanjut. Mahasiswa dituntut lebih aktif dan lebih giat dalam belajar, maksudnya adalah disamping mahasiswa menyelesaikan studinya sesuai dengan yang direncanakan, dalam sistem ini juga memuat ketentuan berapa jam lamanya belajar dengan dosen, kemudian berapa jam belajar berstruktur, dan berapa jam lamanya belajar mandiri.

Dengan kehadiran perpustakaan dalam lembaga pendidikan, merupakan salah satu langkah untuk memfilter tantangan globalisasi dan meningkatkan kualitas sumber daya manusia. Tantangan pertama bagi dunia pendidikan adalah tentang kualitas. Di era globalisasi pada dasarnya muncul era kompetisi. Berbicara kompetisi adalah berbicara keunggulan. Menurut Tilaar [2014: hal. 170] hanya manusia unggul manusia 
yang akan survive di dalam kehidupan yang penuh persaingan. Oleh karena itu salah satu persoalan yang muncul bagaimana upaya untuk meningkatkan kualitas manusia Indonesia.

Perpustakaan perguruan tinggi adalah perpustakaan yang ada di lingkungan universitas dan fakultas, merupakan suatu bagian yang tidak dapat dipisahkan dari suatu perguruan tinggi. Oleh karena itu didalam memenuhi kebutuhan pemakaiannya yang terdiri dari mahasiswa, staf pengajar dan peneliti, maka perpustakaan perguruan tinggi harus mampu menunjang tujuan dari perguruan tinggi itu sendiri yaitu program pengajaran, pendidikan, dan penelitian.

Dalam meningkatkan daya guna dan hasil guna dalam upaya pendayagunaan perpustakaan, maka setiap perpustakaan harus memiliki dan mempersiapkan aspek-aspek dari perpustakaan. Menurut Idris [1998], Karmidi Martoatmojo [1993] bahwa aspek-aspek perpustakaan adalah sebagai berikut [Nasution, 2000: hal. 33]:

1. Aspek koleksi bahan pustaka

Secara umum pembinaan koleksi perpustakaan diarahkan kepada peningkatan koleksi bacaan dalam rangka pemberdayaan perpustakaan semaksimal mungkin, yang diharapkan dapat meningkatkan kualitas sumber daya manusia Indonesia secara keseluruhan. Hal ini diharapkan pada semua jenis perpustakaan dapat meningkatkan mutu koleksi-koleksi buku yang ada di perpustakaan.

2. Aspek gedung dan ruangan

Sebelum dilihat dari data di perpustakaan perguruan tinggi adanya kemajuan yang pesat atau tidak (terutama ditinjau dari segi fasilitas untuk ruangan membaca yang baik, perkembangan koleksi, jumlah pengunjung, anggota, jumlah pembaca). Dengan itu dalam penyusunan program mendatang, perpustakaan perguruan tinggi 
dapat membuat suatu kebutuhan perpustakaan dengan memperhatikan pola pengembangannya.

3. Aspek peralatan dan perlengkapan

Seyogyanya perlengkapan perpustakaan adalah bukubuku dan peralatan elektronik seperti komputer, TV, video, internet, yang dapat memberikan informasi untuk memperluas wawasan pengetahuan.

4. Aspek organisasi dan status

Struktur organisasi perguruan tinggi berdasarkan keputusan Mendikbud RI Bo. 0111/0/93 tanggal 27 Februari 1993. Dengan struktur organisasi yang telah baku tersebut dimana kepala UPT Perpustakaan dalam menjalankan tugas-tugasnya bertanggung jawab kepada Rektor. Dengan demikian kepala perpustakaan perguruan tinggi cukup kuat untuk dapat mengembangkan perpustakaan perguruan tinggi sesuai dengan tuntutan zaman dan meningkatkan minat membaca mahasiswa di perpustakaan.

5. Aspek mutu layanan perpustakaan

Suatu hal yang perlu diperhatikan adalah upaya untuk meningkatkan mutu layanan perpustakaan. Dengan mutu layanan yang tinggi, perpustakaan akan memperoleh banyak pembaca dan selanjutnya akan dapat pengakuan, penghargaan dari pembaca. Upaya untuk meningkatkan mutu layanan perpustakaan tidak boleh dipisahkan dari kegiatan pustakawan sehari-hari. Banyak upaya yang dapat dikerjakan misalnya :

- Sikap ramah dan penampilan yang baik pustakawan dalam memberikan layanan.

- Menyediakan brosur tentang kegiatan yang ada di perpustakaan

- Mengadakan berbagai perlombaan, pengunjung teladan, lomba baca puisi dan sebagainya 
- Mengundang tokoh masyarakat atau seorang pakar untuk mengadakan ceramah dan seminar

- Membuat pameran perpustakaan baik itu pameran buku dan lainnya yang dapat meningkatkan pengetahuan mahasiswa.

6. Promosi dan pemasyarakatan perpustakaan

Bagi perpustakaan perguruan tinggi untuk promosi perlu menyediakan display board agar dapat memperlihatkan buku-buku melalui display tersebut.

7. Kerjasama perpustakaan dan jaringan informasi

Dalam hal ini jaringan informasi, maka semua jenis perpustakaan dapat bekerja sama, dapat saling tukar informasi, perpustakaan yang satu dapat meminta kepada perpustakaan yang lain. Informasi-informasi yang dibutuhkan oleh pemakai jasa perpustakaan dapat saja dipesan melalui sarana telepon, surat dan sarana lainnya.

8. Minat dan kebiasaan membaca

Minat membaca akan tumbuh bilamana lingkungan kehidupan tersedia bahan bacaan yang dapat menumbuhkan minat dan kebiasaan membaca. Bahan bacaan yang bermutu adalah bahan bacaan yang mampu menimbulkan minat baca bagi pembacanya. Oleh karena itu, para pengelola perpustakaan haruslah benar-benar mampu serta mengerti benar jenis bacaan yang dibutuhkan para mahasiswa. Dengan tumbuhnya keinginan membaca diharapkan pembaca akan timbul minat membaca, apabila telah tercipta minat membaca bagi seseorang pada saatnya akan terjadi kebiasaan membaca. Dengan demikian mahasiswa dapat bersikap positif memanfaatkan perpustakaan sesuai dengan tujuan perpustakaan.

Dari uraian di atas, terlihat jelas bahwa aspek mutu layanan perpustakaan merupakan bagian dari aspek-aspek 
perpustakaan yang dianggap sebagai salah satu hal terpenting dalam meningkatkan kualitas perpustakaan. Upaya untuk meningkatkan mutu layanan perpustakaan tidak boleh dipisahkan dari kegiatan pustakawan sehari-hari. Oleh karena itu peran bagi para pustakawan diperlukan untuk dapat memahami ilmu yang mendalami tentang perilaku, hal ini dapat dipelajari dalam ilmu psikologi.

Mengapa psikologi penting dipelajari dalam ilmu perpustakaan?. Ilmu psikologi sangatlah penting bagi pustakawan. Melalui pengetahuan psikologi ini pustakawan dapat meningkatkan profesionalismenya yang akan berpengaruh terhadap kinerja layanan di perpustakaan. Para pustakawan diharapkan dapat berinteraksi dengan baik tidak hanya dengan orang lain tetapi juga mampu memposisikan dirinya dan meningkatkan kinerjanya di dunia perpustakaan.

Di dalam melaksanakan tugasnya, pustakawan harus berinteraksi dengan orang lain. Sebagai bagian dari organisasi, seseorang pustakawan harus dapat bekerjasama dengan atasan, bawahan serta rekan-rekan sekerjanya. Pustakawan juga harus berhubungan dengan pihak-pihak di luar organisasi, seperti penerbit, toko buku, sesama pustakawan, ataupun pihak-pihak lain. Selain itu juga pustakawan akan berinteraksi dengan pemakai perpustakaan. Psikologi adalah ilmu pengetahuan yang mempelajari tingkah laku. Pengetahuan tentang psikologi diharapkan dapat membantu pustakawan dalam berhubungan serta berinteraksi.

\section{SEKILAS TENTANG PSIKOLOGI}

Secara harfiah psikologi [Abu Ahmadi, 2009] umumnya dimengerti sebagai "ilmu jiwa". Pengertian ini didasarkan pada terjemahan kata Yunani : psyche dan logos. Psyche berarti "jiwa" atau "nyawa" atau "alat untuk berpikir". Logos berarti "ilmu" 
atau "yang mempelajari tentang". Dengan demikian, psikologi diterjemahkan ilmu yang mempelajari jiwa.

Sebenarnya terjemahan tersebut kurang tepat, karena bertitik tolak dari pandangan dualisme manusia, yang menganggap bahwa manusia itu terdiri dari dua bagian : jasmani dan rohani. Seolah-olah kalau mendengar kata "ilmu jiwa”, maka terbayang pada kita bahwa yang dipelajari oleh ilmu itu ialah sesuatu yang tidak kelihatan, yang abstrak, yang berada di dalam diri manusia atau makhluk hidup yang lain. Segala sesuatu yang kelihatan, yang bersifat jasmani pada diri manusia tidak menjadi persoalan. Pandangan atau bayangan yang demikian adalah tidak benar, atau keliru. Psikologi adalah ilmu yang ingin mempelajari manusia. Manusia sebagai suatu kesatuan yang bulat antara jasmani dan rohani. Manusia sebagai individu.[Daulay, 204: hal. 9]

Psikologi sebagai suatu ilmu merupakan pengetahuan ilmiah, suatu science yang diperoleh dengan pendekatan ilmiah, kajian-kajian ilmiah yang dijalankan secara terencana, sistematis, terkontrol berdasarkan data empiris. Psikologi sebagai ilmu mengenai aktivitas individual digunakan secara luas, tidak hanya mencakup aktivitas motorik, tetapi juga mencakup aktivitas kognitif, dan emosional. Psikologi merupakan the science of human behavior. Perilaku atau aktivitas-aktivitas manusia mencakup perilaku yang menampak (overbehavioral), maupun perilaku yang tidak menampak (innerbehavior) yang mencakup aktivitas motorik, kognitif, maupun emosional. [Thalib, 2010: hal. 5]

Kalat [2003] dalam bukunya Introduction to Psychology , menyatakan bahwa psikologi berfokus pada studi tentang pikiran dan jiwa (mind and soul), psikologi menurut istilah berasal dari kombinasi dua kata, psyche yang mencakup pengertian spirit atau jiwa (spirit, soul) atau unsur-unsur spiritual, moral dan emosi dasar manusia. Kata psyche juga 
berarti pikiran (the human mind) yang berfungsi sebagai pusat dari apa yang dipikirkan, emosi dan perilaku; dan logos yang berarti ilmu (study). Kalat menegaskan bahwa psikologi secara umum didefinisikan sebagai perilaku dan pengalaman manusia secara sistematis.

Prof.Dr.Sarlito Sarwono [2010] adalah seorang guru besar Psikologi dari Universitas Indonesia menjelaskan bahwa setelah psikologi berkembang luas dan dituntut mempunyai ciri-ciri sebagai suatu disiplin ilmu pengetahuan, maka "jiwa" dipandang terlalu abstrak. Ilmu pengetahuan menghendaki objeknya bisa diamati, dicatat dan diukur. Ini membawa para ahli, dipelopori oleh J.B Watson (1878-1958), memandang psikologi sebagai "ilmu yang mempelajari perilaku". Perilaku dianggap lebih mudah diamati, dicatat dan diukur.

Psikologi memiliki tiga fungsi sebagai ilmu, yaitu :

1. Menjelaskan

Yaitu mampu menjelaskan apa, bagaimana, dan mengapa tingkah laku itu terjadi. Hasilnya penjelasan berupa deskripsi atau bahasan yang bersifat deskriptif.

2. Memprediksikan

Yaitu mampu meramalkan atau memprediksikan apa, bagaimana dan mengapa tingkah laku itu terjadi. Hasil prediksi berupa prognosa, prediksi atau estimasi

3. Pengendalian

Yaitu mengendalikan tingkah laku sesuai dengan yang diharapkan. Perwujudannya berupa tindakan yang sifatnya preventif atau pencegahan, intervensi atau treatment serta rehabilitasi atau perawatan. [http://wikipedia.org/wiki/psikologi]

Psikologi mempengaruhi begitu banyak aspek kehidupan manusia, pelajaran psikologi dapat memberikan pengertian yang lebih baik tentang sebab akibat, misalnya seseorang berpikir 
dan bertindak seperti yang mereka lakukan, dan memberikan pandangan untuk menilai sikap dan reaksi yang dilakukannya sendiri.

Secara keseluruhan, psikologi penting bagi setiap orang yang dalam kehidupannya selalu berhubungan dan bersama orang lain. Psikologi dibutuhkan atau dipelajari oleh mereka yang dalam tugas dan jabatannya akan bekerja bersama orang lain.

\section{$\begin{array}{lll}\text { PENERAPAN } & \text { PSIKOLOGI DALAM ORGANISASI }\end{array}$ PERPUSTAKAAN}

Pada dasarnya setiap orang perlu memiliki pengetahuan psikologi baik psikologi dirinya sendiri atau psikologi orang lain, agar orang dapat bertindak terhadap diri sendiri atau kepada orang lain dengan tidak mengganggu keadaan jiwa orang lain atau jiwanya sendiri. Misalnya karena rasa sakit pada badan tentu menimbulkan kesedihan di hati, yaitu rasa sedih jiwa, tentunya seseorang tersebut tak akan menyakiti diri sendiri atau orang lain.

Psikologi penting bagi pemimpin-pemimpin instansi, lembaga-lembaga, perusahaan-perusahaan dan sebagainya, agar pemimpin dapat menyelenggarakan suasana jiwa baik terhadap bawahannya maupun terhadap koleganya. Dalam hal ini bisa dikaitkan dalam struktur organisasi perpustakaan. Sebagai pimpinan dalam sebuah perpustakaan, maka diharapkan pemimpin mampu menciptakan lingkungan pekerjaan yang kondusif dan dapat menyelenggarakan suasana jiwa yang menyenangkan khususnya terhadap bawahan/pegawai yang ada di lingkungan perpustakaan, misalnya suasana ramah tamah, maka para pegawai di lingkungan perpustakaan dapat bekerja dengan semestinya karena keadaan jiwanya tidak terganggu (tidak merasa tertekan) dan dapat memunculkan perasaan keberhargaan diri. 
Suatu lingkungan kerja yang menyenangkan sangat penting untuk mendorong tingkat kinerja karyawan yang paling produktif. Dalam interaksi sehari-hari, antara atasan dan bawahan, berbagai asumsi dan harapan lain muncul. Ketika atasan dan bawahan membentuk serangkaian asumsi dan harapan mereka sendiri yang terkadang agak berseberangan, perbedaan-perbedaan ini yang akhirnya berpengaruh pada tingkat kinerja. Hal ini nampaknya berlaku juga di perpustakaan. Apabila tidak ada keselarasan antara harapan pustakawan dengan kemampuan perpustakaan sebagai sebuah organisasi, maka pustakawan cenderung malas dan bekerja dengan kurang bersungguh-sungguh. Maka dapat dipastikan kinerja pelayanan perpustakaan akan terganggu dan kurang memuaskan bagi pemustaka.

Untuk menjaga kinerja pelayanan perpustakaan perlu dijalin komunikasi aktif mengenai harapan atau ide-ide pustakawan, sehingga dapat saling mengerti keadaan yang sebenarnya. Perlu juga untuk mengadakan evaluasi secara berkala mengenai kinerja perpustakaan. Dari hasil evaluasi tersebut, pustakawan dapat mengetahui gambaran nyata koleksi perpustakaan, baik dari segi kualitas maupun kuantitas. Tujuan lainnya adalah untuk menghemat tempat dan memberi tempat untuk koleksi baru sehingga koleksi perpustakaan lebih akurat, relevan, dan lebih menarik. Evaluasi dapat dilakukan dengan inventarisasi (stock opname), yaitu memeriksa bahan pustaka yang masih tercatat sesuai dengan katalog perpustakaan atau shelflist, mencatat apakah masih ada di rak, dipinjam, atau hilang.[ Martini \& Farida: 2007.]

Kegiatan ini dilakukan untuk mengetahui keadaan koleksi ditinjau dari jumlah, pemanfaatan koleksi, serta kondisi fisik pustaka. Kegiatan ini dapat dilakukan setahun atau dua tahun sekali, dengan mengerahkan seluruh staf perpustakaan. Namun dengan semakin majunya teknologi informasi untuk 
perpustakaan, kegiatan inventarisasi ini menjadi lebih mudah dan tidak perlu terlalu banyak tenaga. Melalui kegiatan inventarisisasi ini pustakawan juga dapat menentukan rencana pengembangan perpustakaan kedepannya. Supaya perencanaan lebih terarah dan tepat guna, maka perlu dilakukan penelitian mendalam mengenai beberapa hal yang berhubungan langsung dengan perpustakaan. Hal-hal yang perlu diteliti antara lain:

1. Pemustaka

Pemustaka adalah tujuan utama perpustakaan. Pustakawan perlu mengkaji tentang pemustaka, kebutuhan informasi pemustaka dan kepuasan pemustaka terhadap layanan jasa perpustakaan. Semakin tinggi tingkat pemenuhan informasi oleh perpustakaan, dan semakin tinggi tingkat kepuasan pemustaka, berarti perpustakaan semakin bagus.

2. Inventarisasi

Survei dilakukan untuk mengetahui kekuatan koleksi yang dimiliki, mulai dari mutu, harga dan tingkat keterpakaiannya, dan bagaimana cara menginformasikannya. Dengan pengaplikasian teknologi informasi dan komunikasi, inventarisasi ini menjadi lebih praktis. Untuk perpustakaan yang sudah menerapkan automasi perpustakaan, pustakawan tinggal mengoperasikan aplikasi yang digunakan di perpustakaan utuk menginventarisasi seluruh koleksi perpustakaan yang selanjutnya dapat dicetak.

3. Perkembangan teknologi informasi.

Survei dilakukan untuk mengetahui kemajuan teknologi, mulai dari spesifikasi, harga, kualitas hingga cara pemeliharaannya, agar perpustakaan dapat memanfaatkan teknologi yang praktis dan sesuai dengan tingkat kebutuhan. Selain software yang dibeli, sekarang juga sudah bisa mendapatkan aplikasi gratis di internet. 
4. Penjajagan kerjasama

Tidak ada satu perpustakaan pun yang dapat memenuhi kebutuhan semua orang dengan hanya mengandalkan koleksi sendiri. Untuk itu perlu diadakan kerjasama dengan perpustakaan lain atau lembaga sumber informasi lain. Lembaga yang dimaksud adalah lembaga pemerintahan, lembaga LSM, penerbit dan toko buku, universitas, atau perpustakaan-perpustakaan lain seperti Perpustakaan Nasional.

5. Kinerja pustakawan dan staf perpustakaan

Selain perpustakaanya, perlu juga dilakukan penelitian mengenai tingkat kinerja seluruh staf perpustakaan. Dengan demikian, setelah mereka mengetahui tingkat prestasi masing-masing, mereka dapat diarahkan untuk pengembangan selanjutnya. Selain itu, individu yang mendapat penilaian kurang bagus juga dapat termotivasi untuk memiliki kemauan untuk maju dan meningkatkan pengetahuan dan keterampilanya.

\section{PENDIDIKAN PSIKOLOGI BAGI PUSTAKAWAN UNTUK PROFESIONALITAS DAN LAYANAN}

Untuk mengembangkan layanan perpustakaan dituntut adanya pustakawan yang profesional dan berkompeten. Kompetensi pustakawan sebagai sebuah profesi juga dituntut agar profesional dalam melaksanakan tugas pokoknya, yaitu melayani kebutuhan informasi bagi pemakainya. Untuk memperoleh predikat profesional tersebut seorang pustakawan harus memiliki kompetensi sesuai standar yang telah ditentukan. Tanpa sikap profesional dari pustakawannya, perpustakaan yang modern, lengkap dan canggih akan kurang berarti. Sehingga perlu dikembangkan dengan baik upayaupaya peningkatan profesionalitas pustakawan dalam rangka peningkatan layanan perpustakaan. 
Oleh karena itu sangatlah diperlukan bagi seorang pustakawan untuk dijejali dengan ilmu-ilmu yang berhubungan dengan perilaku dan bagaimana aplikasi dari perilaku tersebut dalam berinteraksi dengan dunia luar. Ini lah salah satu fungsi dari ilmu psikologi. Pendidikan psikologi yang penting dan yang harus dipahami oleh seorang pustakawan demi peningkatan profesionalitas dan layanan dalam perpustakaan, diantaranya secara garis besar adalah :

- Teori belajar

Berfungsi untuk membahas teori-teori belajar dari para tokoh psikologi kemudian pengaplikasiannya dalam lingkungan kerja perpustakaan, seta bagaimana menciptakan konsekuensi yang positif kepada pengunjung perpustakaan sehingga dapat meningkatkan tingkah lakunya, serta memberikan kesempatan kepada pustakawan untuk memahami lingkungannya melalui teori-teori belajar.

- Teori motivasi

Motivasi sendiri mempunyai pengertian suatu dorongan psikologis dari dalam diri seseorang yang menyebabkan ia berperilaku secara tertentu terutama di dalam lingkungan ia bekerja. [Atkinson: hal. 7]

- Teori sikap dan persepsi

Berfungsi untuk memberikan pemahaman bahwa betapa pentingnya sikap dan persepsi ini dikaitkan dengan perilaku atau perbuatan manusia dalam kehidupan sehari-hari. Sikap yang ada pada seseorang akan memberikan warna atau corak pada perilaku atau perbuatan orang yang bersangkutan. Dengan mengetahui sikap seseorang, individu akan mendapatkan gambaran kemungkinan perilaku yang timbul dari orang yang bersangkutan. [Sarwono: hal. 227]

- Teori hubungan interpersonal 
Kemampuan seseorang dalam menjalin suatu hubungan interpersonal sangat penting untuk membina hubungan yang baik dengan orang lain, baik dalam kehidupan sehari-hari maupun dalam lingkungan pekerjaan. Seseorang tidak begitu saja mempunyai keterampilan untuk berinteraksi secara efektif dengan orang lain. Kemampuan ini tidak bersifat bawaan dan tidaklah muncul secara ajaib, tetapi dipelajari.

- Teori dinamika kelompok

Berfungsi untuk memberikan pemahaman tentang suatu kelompok yang tidak dapat dilepaskan dari adanya interaksi antara anggota satu dengan anggota lain. Pengetahuan tentang proses-proses yang terjadi dalam kelompok serta bagaimana seseorang individu berperilaku dalam kelompok.

- Teori kepribadian

Berfungsi untuk memberikan pemahaman tentang kepribadian yang diharapkan dari pustakawan dan akan mengingatkan setiap individu untuk berusaha membentuk diri menjadi orang yang memiliki kepribadian yang menyenangkan dan bersahabat dalam memberikan layanan di perpustakaan.

\section{HUBUNGAN PSIKOLOGI, KOMUNIKASI DAN ILMU PERPUSTAKAAN}

Ilmu komunikasi yang telah tumbuh sebagai ilmu yang berdiri sendiri kemudian melakukan 'perkawinan' dengan ilmuilmu lainnya yang pada gilirannya melahirkan pelbagai subdisiplin seperti komunikasi politik (dengan ilmu politik), sosiologi komunikasi massa (dengan sosiologi), psikologi komunikasi dan psikologi perpustakaan (dengan psikologi). Dengan demikian, psikologi komunikasi dan psikologi perpustakaan pun memiliki hubungan yang sangat erat, 
sehingga dapat didefinisikan sebagai ilmu yang berusaha menguraikan, meramalkan, dan mengendalikan peristiwa mental dan behavioral dalam komunikasi khususnya dalam ruang lingkup perpustakaan.

Komunikasi menurut Rakhmat [2011] adalah peristiwa sosial (peristiwa yang terjadi ketika manusia berinteraksi dengan manusia lain). Mencoba menganalisis peristiwa sosial secara psikologis, membawa kita pada psikologi sosial. Bila ditanyakan letak psikologi komunikasi, maka cenderung meletakkannya sebagai bagian dari psikologi sosial. Karena itu menurut Jalaluddin Rakhmat pendekatan psikologi sosial juga merupakan pendekatan psikologi komunikasi.

Dunia perpustakaan merupakan bagian dari ilmu sosial, demikian pula dengan ilmu psikologi yang merupakan bagian dari ilmu sosial dan berinteraksi erat dengan manusia. Manusia secara alami selalu membutuhkan hubungan atau komunikasi dengan manusia yang lain. Di samping itu manusia juga mempunyai dorongan-dorongan lain seperti dorongan ingin tahu, dorongan ingin mengaktualisasikan diri dan lain sebagainya. Dorongan-dorongan tersebut akan dapat dipenuhi dengan mengadakan komunikasi dengan sesamanya. [Walgito: 2003, hal. 65]

Dengan komunikasi seseorang dapat menyampaikan informasi, ide ataupun pemikiran, pengetahuan, konsep dan lain-lain kepada orang lain secara timbal balik, baik sebagai penyampai maupun sebagai penerima komunikasi. Dengan komunikasi, manusia dapat berkembang dan dapat melangsungkan kehidupan bermasyarakat. Demikian pentingnya makna komunikasi dalam menjalin interaksi yang hangat antar sesama manusia, sehingga psikologi menspesifikasikannya ke dalam cabang ilmu psikologi yakni psikologi komunikasi. Jelas terlihat hubungan yang sangat erat 
antara psikologi, komunikasi dan pengaplikasiannya dalam dunia perpustakaan.

Pada akhir millennium kedua ini, disadari sepenuhnya bahwa komunikasi merupakan bagian esensial dalaam kehidupan manusia. Kemampuan menjalin persahabatan, bergaul dengan teman sejawat, keefektifan berteman, kesuksesan studi dan berbagai interaksi social lainnya sangat ditentukan oleh kemampuan komunikasi. Sebaliknya, ketidakmampuan berkomunikasi mengakibatkan dampak negatif seperti kegagalan membangun dan memelihara hubungan sosial, mengembangkan kepemimpinan organisasi, menyesuaikan diri dengan situasi baru, dan interaksi dengan orang lain yang berasal dari latar budaya yang berbeda. [Thalib: 2010 Hal. 135].

Definisi mengenai komunikasi dapat berbeda antara ahli satu dengan yang lain. Secara umum komunikasi merupakan proses penyampaian dan penerimaan lambang-lambang yang mengandung arti, baik yang berwujud informasi-informasi, pemikiran-pemikiran, pengetahuan ataupun yang lain-lain dari penyampai (komunikator) kepada penerima (komunikan). Dalam komunikasi yang penting adanya pengertian bersama dari lambang-lambang tersebut, dan karena itu komunikasi merupakan proses sosial. [Katz. 1978. Dalam Bimo Walgito: 2003. Hal. 65]. Sebagai contoh, komunikasi antara ayah dan ibu, antara seorang anak dengan orang tuanya, antara seorang seorang pekerja dengan seorang karyawan, antara seorang pimpinan dengan seorang pegawainya, antara dua orang yang baru berjumpa, dan seterusnya.

Secara keseluruhan komunikasi menunjukkan adanya saling ketergantungan atau hubungan antara dua orang atau lebih dalam proses komunikasi. Agar komunikasi dapat berlangsung secara efektif, khususnya dalam hal ini proses komunikasi dalam dunia perpustakaan diperlukan keterampilan 
khusus baik secara teoritis maupun aplikasi praktis. Keterampilan ini merupakan suatu hasil belajar berupa penguasaan konsep maupun pengalaman praktis yang mencakup kemampuan menyampaikan pesan secara akurat, keterampilan mengembangkan hubungan yang harmonis, keterampilan menerima, mengolah, menganalisis dan menginterpretasikan fenomena hubungan sosial (fisik, psikologis, social), keterampilan memahami ekspresi verbal maupun non verbal. Untuk dapat memahami keterampilanketerampilan dalam proses komunikasi ini, bagi para pustakawan dapat mempelajarinya dalam cabang ilmu psikologi yaitu dalam psikologi komunikasi.

Dalam upaya memahami keterampilan-keterampilan proses komunikasi ini, diantaranya yang sangat penting adalah keramah tamahan. Apabila pustakawan ramah terhadap pemustaka, mereka akan nyaman untuk berkomunikasi dengan para pustakawan. Melalui jalinan komunikasi yang baik inilah dapat tercapai relevansi yang tinggi terhadap informasi yang dibutuhkan pemustaka. Komunikasi dalam lingkup perpustakaan ini tidak hanya terbatas pada komunikasi "face to face" pustakawan dan pemustaka saja. Komunikasi disini dapat diartikan sebagai suatu proses penyampaian dan penerimaan berita, pesan atau informasi dari seseorang ke orang lain. Komunikasi ini tidak akan terjadi apabila tidak ada komunikator, yaitu pesan yang disampaikan dan komunikan yang menerima pesan tersebut.

Namun demikian, komunikasi dalam kenyataannya tidak seperti yang dikatakan itu. Masih terdapat sejumlah kemungkinan penghalang, dan penyaring di dalam proses komunikasi. Pengirim (komunikator) mencoba untuk mengkodekan berita, pesan atau buah pikirannya ke dalam suatu bentuk yang dianggapnya paling tepat. Kemudian kodekode tersebut dikirimkan, dan penerima (komunikan) berusaha 
memahami kode tersebut. Tetapi di dalam proses perjalanan berita tadi banyak terdapat serangkaian persepsi atau gangguan yang dapat mengurangi kejelasan dan ketepatan pesan atau berita. Halangan paling besar untuk mencapai komunikasi yang efektif adalah jika terjadi aneka macam persepsi atau gangguan. Misalnya, komunikator menyampaikan pesan dengan tidak jelas dan menggunakan saluran transmisi yang salah mungkin si komunikan sedang memikirkan hal lain pada saat ia harus menerima pesan tersebut. Dalam kondisi seperti itu ia hanya mendengar tetapi mungkin tidak tahu tentang isi pesannya.

\section{KESIMPULAN}

Pada era informasi dan komunikasi ini, manusia akan berada di bawah naungan dunia atau peradaban global. Peradaban global ini akan membawa manusia kepada kompetisi, akan terjadi pertarungan keunggulan, secara alami akan terjadi seleksi alam siapa yang unggul maka individu tersebut yang akan bertahan hidup. Agar dapat bertahan hidup maka setiap individu memerlukan pendidikan dalam kehidupannya. Sarana dan prasarana dalam pendidikan juga harus diperhatikan, salah satunya adalah kehadiran perpustakaan.

Perpustakaan menempati posisi strategis dalam kehidupan umat manusia, bahkan dapat dipakai sebagai tolok ukur tinggi rendahnya peradaban suatu bangsa. Salah satu faktor signifikan dalam meningkatkan kualitas sumber daya manusia ditentukan oleh keberadaan dan pemanfaatan perpustakaan. Dengan kehadiran perpustakaan dalam lembaga pendidikan, merupakan salah satu langkah untuk menangkis tantangan globalisasi dan meningkatkan kualitas sumber daya manusia.Dalam mengembangkan perpustakaan, perlu adanya dukungan dari ilmu-ilmu lainnya, salah satunya adalah ilmu psikologi. Ilmu psikologi dianggap dapat meningkatkan 
profesionalisme pustakawan karena ilmu psikologi sendiri adalah ilmu yang membahas tentang perilaku. Oleh karena itu keberadaan perpustakaan sebagai unit pengelola informasi sangat penting untuk mendukung terjadinya komunikasi yang efektif di masyarakat. 


\section{DAFTAR PUSTAKA}

Abu Ahmadi. Psikologi Umum. Jakarta : PT Rineka Cipta. 2009. Atkinson, Rita. Pengantar Psikologi. Edisi kedelapan. Jakarta : Erlangga. 1999.

Daulay, Haidar. Pendidikan Islam dalam Sistem Pendidikan Nasional di Indonesia. Jakarta : PrenadaMedia Group. 2014.

Daulay, Nurussakinah. Pengantar Psikologi dan Pandangan Al Quran tentang Psikologi. Jakarta : PrenadaMedia Group. 2014.

Kalat. Definition of Psychology. APA Public Communication. Retrived Desember 10, 2003, from the www.apa.org/about.ok Cached.

Martini, Nina \& Farida, Ida. Psikologi Perpustakaan. Jakarta : Universitas Terbuka. 2007.

Nasution, Isleini. Hubungan Sikap Mahasiswa Terhadap Keberadaan Perpustakaan Universitas Medan Area dengan Minat Membaca pada Mahasiswa UMA Medan. Skripsi. Fakultas Psikologi Universitas Medan Area. 2000

Rimbarawa, Kosan. Supriyanto. Aksentuasi Pustakawan dan Perpustakaan. Jakarta: Ikatan. 2006

Sarwono, Sarlito. Pengantar Psikologi Umum. Jakarta : Rajawali Press. 2010.

RajaGrafindoPersada. 2001

Sobur, Alex. Psikologi Umum. Bandung: Pustaka Setia. 2011.

Thalib, Syamsul B. Psikologi Pendidikan Berbasis Analisis Empiris Aplikatif. Jakarta : Prenada Media Group. 2010.

Walgito, Bimo. Psikologi Sosial Suatu Pengantar. Yogyakarta : Andi Offset. 2003.

http://wikipedia.org/wiki/psikolog 